\title{
Pelaksanaan Program Badan Usahan Milik Desa (Bumdes) di Desa Penarun Kecamatan Batin VIII Kabupaten Sarolangung
}

\author{
Kemas Abdul Somad ${ }^{1}$, H. Zikri ${ }^{2}$ \\ Fakultas Hukum Universitas Batanghari \\ Correspondence email: kemassomad5@gmail.com
}

\begin{abstract}
Abstrak. Tujuan penulisan dalam penelitian ini yaitu untuk mengetahui dan menganalisis Pelaksanaan Program Badan Usahan Milik Desa (BUMDes) di Desa Penarun Kecamatan Batin VIII Kabupaten Sarolangun. Dalam penelitian ini Penulis menggunakan metode penelitian yuridis empiris. Adapun hasil dari penelitian ini yaitu program Badan Usahan Milik Desa (BUMDes) di Desa Penarun Kecamatan Batin VIII Kabupaten Sarolangun tidak terlaksana dengan efektif dimana program usaha yang dijalankan tidak berkembang dan tidak dapat membantu masyarakat Desa Penarun Kecamatan Batin VIII Kabupaten Sarolangun untuk meningkatkan perekonomiannya. Kendala pelaksanaan program Badan Usahan Milik Desa (BUMDes) di Desa Penarun Kecamatan Batin VIII Kabupaten Sarolangun terdiri dari beberapa faktor yaitu tidak adanya Sumber Daya Manusia yang memiliki inovasi dan kreatifitas pada Badan Usahan Milik Desa (BUMDes) Desa Penarun Kecamatan Batin VIII Kabupaten Sarolangun serta tidak adanya peran serta masyarakat untuk mengembangkan Badan Usahan Milik Desa (BUMDes) Desa Penarun Kecamatan Batin VIII Kabupaten Sarolangun. Upaya yang dilakukan untuk mengatasi kendala pelaksanaan program Badan Usahan Milik Desa (BUMDes) di Desa Penarun Kecamatan Batin VIII Kabupaten Sarolangun yaitu melakukan pengembangan unit usaha serta menjalain kerjasama dengan Badan Usahan Milik Desa (BUMDes) Lainnya.
\end{abstract}

Kata Kunci: Pelaksanaan, Program, Badan Usahan Milik Desa

\begin{abstract}
The purpose of writing in this study is to determine and analyze the implementation of the Village Owned Enterprise Program (BUMDes) in Penarun Village, Batin VIII District, Sarolangun Regency. In this study the author uses empirical juridical research methods. The results of this research are that the Village Owned Enterprises (BUMDes) program in Penarun Village, Batin VIII District, Sarolangun Regency is not implemented effectively where the business program that is being run is not developing and cannot help the people of Penarun Village, Batin VIII District, Sarolangun Regency to improve their economy. The obstacles to implementing the Village-Owned Enterprises (BUMDes) program in Penarun Village, Batin VIII District, Sarolangun Regency consist of several factors, namely the absence of Human Resources who have innovation and creativity in Village-Owned Enterprises (BUMDes) Penarun Village, Batin VIII District, Sarolangun Regency and not the existence of community participation to develop Village Owned Enterprises (BUMDes) Penarun Village, Batin VIII District, Sarolangun Regency. Efforts were made to overcome obstacles to implementing the Village-Owned Enterprises (BUMDes) program in Penarun Village, Batin VIII District, Sarolangun Regency, namely developing business units and establishing cooperation with other Village-Owned Enterprises (BUMDes).
\end{abstract}

Keywords: Implementation, Program, Village Owned Enterprises

\section{PENDAHULUAN}

Sumberdaya ekonomi yang tumbuh di kawasan Desa diambil oleh kekuatan yang lebih besar, sehingga Desa kehabisan sumberdaya dan menimbulkan arus urbanisasi penduduk Desa ke kota. Kondisi ini yang menciptakan ketidakadilan, kemiskinan maupun keterbelakangan senantiasa melekat pada Desa.

Sebagai salah satu upaya pemerintah untuk mewujudkan pemerataan pembangunan hingga ke Desa, maka dibentuklah Undang-Undang Republik Indonesia Nomor 6 Tahun 2014 Tentang Desa, yang menjadi dasar untuk mengatur dan mengurus kepentingan masyarakat desa.

Berdasarkan Pasal 1 angka 1 Undang-Undang Republik Indonesia Nomor 6 Tahun 2014 Tentang Desa, diatur bahwa:

Desa adalah kesatuan masyarakat hukum yang memiliki batas wilayah yang berwenang untuk mengatur dan mengurus urusan pemerintahan, kepentingan masyarakat setempat berdasarkan prakarsa masyarakat, hak asal usul, dan/atau hak tradisional yang diakui dan dihormati dalam sistem pemerintahan Negara Kesatuan Republik Indonesia.

Badan Usaha Milik Desa berdasarkan Pasal 1 angka 6 Undang-Undang Republik Indonesia Nomor 6 Tahun 2014 Tentang Desa, merupakan: "Badan usaha yang seluruh atau sebagian besar modalnya dimiliki oleh Desa melalui penyertaan secara langsung yang berasal dari kekayaan Desa yang dipisahkan guna mengelola aset, jasa pelayanan, dan usaha lainnya untuk sebesarbesarnya kesejahteraan masyarakat Desa".

\footnotetext{
${ }^{1}$ Dosen Fakultas Hukum Universitas Batanghari

2 Dosen Fakultas Hukum Universitas Batanghari
} 
Badan Usaha Milik Desa dapat menjalankan usaha di bidang ekonomi dan/atau pelayanan umum sesuai dengan ketentuan peraturan perundang-undangan yang disepakati melalui musyawarah, Hasil usaha Badan Usaha Milik Desa berdasarkan Pasal 89 Undang-Undang Republik Indonesia Nomor 6 Tahun 2014 Tentang Desa, dimanfaatkan untuk pengembangan usaha dan Pembangunan desa, pemberdayaan masyarakat desa, dan pemberian bantuan untuk masyarakat miskin melalui hibah, bantuan sosial, dan kegiatan dana bergulir yang ditetapkan dalam anggaran pendapatan dan belanja desa.

Selanjutnya di dalam Pasal 90 Undang-Undang Republik Indonesia Nomor 6 Tahun 2014 Tentang Desa, diatur bahwa Pemerintah, Pemerintah Daerah Provinsi, Pemerintah Daerah Kabupaten/Kota, dan Pemerintah Desa mendorong perkembangan Badan Usaha Milik Desa dengan memberikan hibah dan/atau akses permodalan, Melakukan pendampingan teknis dan akses ke pasar dan memprioritaskan badan usaha milik desa dalam pengelolaan sumber daya alam di desa.

Berdasarkan penjelasan tersebut dapat dipahami bahwa Badan Usaha Milik Desa dapat menjadi wadah percepatan pembangunan desa apabila program-program yang telah dibentuk sesuai dengan kebutuhan masyarakat dan dilaksanakan dengan semaksimal mungkin.

Badan Usaha Milik Desa diharapkan mampu menjadi motor penggerak kegiatan ekonomi di desa yang juga berfungsi sebagai lembaga sosial dan komersial. Badan Usaha Milik Desa sebagai lembaga sosial berpihak kepada kepentingan masyarakat melalui kontribusinya dalam penyediaan pelayanan sosial, sedangkan sebagai lembaga komersial Badan Usaha Milik Desa bertujuan mencari keuntungan untuk meningkatkan pendapatan desa.

Badan Usaha Milik Desa menjadi salah satu bentuk Badan Usaha yang berperan dalam pembangunan nasional. Pemerintah dapat menciptakan sebuah usaha yang mendorong perkembangan perekonomian secara baik dalam meningkatkan kesejahteraan anggota dan masyarakat disekitarnya. Bila dilihat melalui peran Pemerintah Desa dalam pelaksanaan program pemberdayaan masyarakat selama ini, maka melalui model Badan Usaha Milik Desa ini diharapkan terjadi perubahan peran Pemerintah Desa dalam pengembangan ekonomi lokal dan pemberdayaan masyarakat.

Badan Usaha Milik Desa diatur pula dalam Peraturan Menteri Desa, Pembangunan Daerah Tertinggal, dan Transmigrasi Republik Indonesia Nomor 4 Tahun 2015 Tentang Pendirian, Pengurusan Dan Pengelolaan, Dan Pembubaran Badan Usaha Milik Desa, di dalam Pasal 3 peraturan ini diatur bahwa:

Pendirian BUM Desa bertujuan:

1. Meningkatkan perekonomian Desa.

2. Mengoptimalkan aset Desa agar bermanfaat untuk kesejahteraan Desa.

3. Meningkatkan usaha masyarakat dalam pengelolaan potensi ekonomi Desa.

4. Mengembangkan rencana kerja sama usaha antar desa dan/atau dengan pihak ketiga.

5. Menciptakan peluang dan jaringan pasar yang mendukung kebutuhan layanan umum warga; Membuka lapangan kerja.

6. Meningkatkan kesejahteraan masyarakat melalui perbaikan pelayanan umum, pertumbuhan dan pemerataan ekonomi Desa, dan

7. Meningkatkan pendapatan masyarakat Desa dan Pendapatan Asli Desa.

Dalam penelitian ini penulis melakukan penelitian mengenai Pelaksanaan Program Badan Usahan Milik Desa di Desa Penarun Kecamatan Batin VIII Kabupaten Sarolangun, di wilayah ini pembentukan Badan Usahan Milik Desa diatur melalui Peraturan Bupati Sarolangun Nomor 56 Tahun 2018 Tentang Pendirian, Pengurusan Dan Pengelolaan, Dan Pembubaran Badan Usaha Milik Desa. Tujuan pendirian Badan Usahan Milik Desa di dalam Peraturan Bupati tersebut tidak berbeda dari tujuan pembentukan Badan Usahan Milik Desa sebagaimana diatur dalam Pasal 3 Peraturan Menteri Desa, Pembangunan Daerah Tertinggal, dan Transmigrasi Republik Indonesia Nomor 4 Tahun 2015 Tentang Pendirian, Pengurusan Dan Pengelolaan, Dan Pembubaran Badan Usaha Milik Desa.

Berdasarkan data awal yang penulis peroleh diketahui bahwa Badan Usaha Milik Desa di Desa Penarun Kecamatan Batin VIII Kabupaten Sarolangun terdapat Badan Usaha Milik Desa yang telah dibentuk satu tahun terakhir dengan wacana kedepan adalah program unit usaha di bidang pertanian yaitu sebagai penyalur pupuk bersubsidi, bibit karet unggul dan bibit sawit unggul. Akan tetapi program Program Badan Usahan Milik Desa (BUMDes) di Desa Penarun Kecamatan Batin VIII Kabupaten Sarolangun tersebut tidak terlaksana karena sebagian besar masyarakat justru masih menuplai pupuk bersubsidi, bibit karet unggul dan bibit sawit unggul dari luar desa, selain itu persepsi masyarakat desa yang kurang memberikan respon positif terhadap program ini juga mengakibatkan fakumnya program Badan Usahan Milik Desa (BUMDes) tersebut.

Badan Usaha Milik Desa di Desa Penarun Kecamatan Batin VIII Kabupaten Sarolangun tersebut seharusnya dapat memenuhi kebutuhan masyarakat Desa Penarun Kecamatan Batin VIII Kabupaten Sarolangun tersebut khususnya di bidang pertanian mengingat bahwa kebutuhan masyarakat Desa Penarun Kecamatan Batin VIII Kabupaten Sarolangun tersebut khususnya terhadap pupuk bersubsidi sangat tinggi. 
Tidak berjalannya program Badan Usaha Milik Desa di Desa Penarun Kecamatan Batin VIII Kabupaten Sarolangun tersebut tentu harus di atasi dengan segera mengingat tujuan pembentukan Badan Usaha Milik Desa adalah untuk meningkatkan usaha masyarakat dalam pengelolaan potensi ekonomi Desa maka sudah seharusnya Badan Usaha Milik Desa menjadi lembaga yang mampu memenuhi kebutuhan masarakat, oleh karena itu maka penulis tertarik mengangkat permasalahan tersebut dalam sebuah proposal skripsi dengan judul: "Pelaksanaan Program Badan Usahan Milik Desa (BUMDes) di Desa Penarun Kecamatan Batin VIII Kabupaten Sarolangun”.

Berdasarkan latar belakang yang dikemukakan di atas, maka dapat diketahui permasalahan pokok yang akan dibahas dalam penelitian ini, adalah :

1. Bagaimana Pelaksanaan Program Badan Usahan Milik Desa (BUMDes) di Desa Penarun Kecamatan Batin VIII Kabupaten Sarolangun?

2. Apakah yang menjadi kendala Pelaksanaan Program Badan Usahan Milik Desa (BUMDes) di Desa Penarun Kecamatan Batin VIII Kabupaten Sarolangun?

Tujuan yang akan dihasilkan dalam penelitian ini sebagai berikut:

1. Untuk mengetahui Pelaksanaan Program Badan Usahan Milik Desa (BUMDes) di Desa Penarun Kecamatan Batin VIII Kabupaten Sarolangun.

2. Untuk menjelaskan kendala Pelaksanaan Program Badan Usahan Milik Desa (BUMDes) di Desa Penarun Kecamatan Batin VIII Kabupaten Sarolangun.

\section{METODE}

Metode penelitian digunakan untuk mempermudah peneliti dalam melakukan suatu penelitian, dimana metode penelitian ini berkaitan dengan prosedur atau cara yang harus dilakukan peneliti sehingga dengan adanya metode penelitian ini peneliti harus menggunakan langkah-langkah yang teratur dan sistematis di dalam mencari bahan atau sumber data yang diperlukan untuk disajikan dalam suatu penelitian.

Hal yang demikian juga senada dengan pendapat Sukandarrumidi yang menyatakan bahwa metode penelitian merupakan cara utama yang digunakan peneliti untuk mencapai tujuan dan menentukan jawaban atas masalah yang diajukan. ${ }^{3} \mathrm{Jadi}$, metode penelitian itu merupakan suatu cara cara yang digunakan para peneliti dalam memecahkan masalah yang sedang diteliti atau yang sedang dihadapi. Adapun metode penelitian yang dilakukan dalam penelitian ini sebagai berikut :

1. Tipe penelitian

Tipe penelitian yang dipergunakan dalam penulisan ini adalah penelitian yuridis empiris. Dalam pendekatan penelitian ini ditujukan untuk mengetahui sejauhmana bekerjanya hukum di dalam masyarakat, sehingga dapat dikatakan untuk mengetahui kesenjangan antara das sollen dengan das sein. Karena itulah penulis melakukan pengamatan terhadap Pelaksanaan Program Badan Usahan Milik Desa (BUMDes) di Desa Penarun Kecamatan Batin VIII Kabupaten Sarolangun.

2. Spesifikasi Penelitian

Spesifikasi Penelitian dalam proposal skripsi ini adalah bersifat deskriptif dan analisis, dengan maksud memberikan data, menggambarkan dan menganalisis tentang keadaan dan gejala-gejala yang berkaitan dengan Pelaksanaan Program Badan Usahan Milik Desa (BUMDes) di Desa Penarun Kecamatan Batin VIII Kabupaten Sarolangun.

3. Sampel Penelitian

Sampel penelitian dalam penulisan proposal skripsi ini diambil dengan menggunakan teknik purposive sample, yaitu Memilih sampel berdasarkan penilaian tertentu karena unsur-unsur atau unit-unit yang dipilih dianggap mewakili populasi. Penelitian terhadap unsur-unsur atau unit-unit yang dijadikan sampel harus berdasarkan pada alasan yang logis artinya dalam pengambilan sampel diambil unit-unit sampel sedemikian rupa sehingga sampel tersebut benar-benar mencerminkan ciri-ciri dari populasi yang ditentukan. Ciri atau karakter tersebut diperoleh berdasarkan pengetahuan atau informasi yang telah dicermati sebelumnya. Ciri-ciri ini dapat berupa pengetahuan, pengalaman, pekerjaan, dan atau jabatan yang sama.

4. Teknik Analisis

Pengolahan data dilakukan dengan cara data yang dikumpulkan baik data primer maupun data sekunder diseleksi dan diklasifikasikan dalam bentuk yuridis, kemudian dianalisis secara kualitatif. Analisis secara kualitatif adalah: "analisis data yang tidak menggunakan angka melainkan memberikan gambaran-gambaran (deskripsi) dengan kata-kata atas temuan-temuan, dan karenanya ia lebih mengutamakan mutu atau kualitas dari data".

${ }^{3}$ Sukandarrumidi, Metodologi Penelitian: Petunjuk Praktis untuk Peneliti Pemula, (Yogyakarta : Gajah Mada University Press, 2006), hal 111. 


\section{HASIL DAN PEMBAHASAN}

\section{Pelaksanaan Program Badan Usahan Milik Desa (BUMDes) di Desa Penarun Kecamatan Batin VIII Kabupaten Sarolangun}

Berdasarkan hasil penelitian yang penulis lakukan diketahui bahwa Badan Usahan Milik Desa (BUMDes) di Desa Penarun Kecamatan Batin VIII Kabupaten Sarolangun dibentuk pada bulan Maret tahun 2019 program unit usaha di bidang pertanian yaitu sebagai penyalur pupuk bersubsidi, bibit karet unggul dan bibit sawit unggul.

Badan Usahan Milik Desa (BUMDes) Desa Penarun Kecamatan Batin VIII Kabupaten Sarolangun dibentuk berdasarkan kesepakatan musyawarah desa dan berdasarkan inisiatif dari Kepala Desa Penarun Kecamatan Batin VIII Kabupaten Sarolangun yang memperoleh arahan untuk membentuk Badan Usahan Milik Desa (BUMDes) di setiap desa di Kabupaten Sarolangun.

Badan Usahan Milik Desa (BUMDes) Desa Penarun Kecamatan Batin VIII Kabupaten Sarolangun dibentuk berdasarkan Peraturan Bupati Sarolangun Nomor 56 Tahun 2018 Tentang Pendirian, Pengurusan dan Pengelolaan, dan Pembubaran Badan Usaha Milik Desa.Pembentukan Badan Usahan Milik Desa (BUMDes) Desa Penarun Kecamatan Batin VIII Kabupaten Sarolangun dipertimbangkan dengan potensi desa yaitu sebagian besar masyarakat Desa Penarun Kecamatan Batin VIII Kabupaten Sarolangun mengandalkan perekonomian dari sektor perkebunan karet dan kelapa sawit, sehingga dalam musyawarah desa disepakati bahwa Badan Usahan Milik Desa (BUMDes) Desa Penarun Kecamatan Batin VIII Kabupaten Sarolangun diharapkan dapat membantu masyarakat Desa Penarun Kecamatan Batin VIII Kabupaten Sarolangun untuk memperoleh pupuk bersubsidi, bibit karet unggul dan bibit sawit unggul.

Badan Usahan Milik Desa (BUMDes) Desa Penarun dibentuk dengan modal awal dari Anggaran Pendapat dan Belanja Desa yang dipergunakan untuk mendirikan bangunan Badan Usahan Milik Desa (BUMDes) Desa Penarun dan kas awal. Musyawarah Desa Penarun Kecamatan Batin VIII Kabupaten Sarolangun menyepakati bahwa Badan Usahan Milik Desa (BUMDes) Desa Penarun ditujukan untuk mengelola bantuan-bantuan baik dari pihak swasta maupun Pemerintah Daerah Kabupaten Sarolangun berupa kebutuhan masyarakat di bidang perkebunan.

Selama ini Desa Penarun Kecamatan Batin VIII Kabupaten Sarolangun cukup banyak mendapat bantuan di sektor perkebunan, baik itu dari pihak swasta maupun dari Pemerintah Daerah Kabupaten Sarolangun, dari kesepakatan desa maka bantuan tersebut diserahkan pada Badan Usahan Milik Desa (BUMDes) Desa Penarun untuk dikelola dan didistribusikan pada masyarakat Desa (BUMDes) Desa Penarun Kecamatan Batin VIII Kabupaten Sarolangun.

Bantuan-bantuan yang diperoleh dari pihak swasta maupun Pemerintah Daerah Kabupaten Sarolangun tersebut berupa pupuk bersubsidi, bibit karet unggul dan bibit sawit unggul. Jefri (Kepala Badan Usahan Milik Desa (BUMDes) Desa Penarun Kecamatan Batin VIII Kabupaten Sarolangun) mengatakan bahwa pupuk bersubsidi, bibit karet unggul dan bibit sawit unggul tersebut kemudian disalurkan kepada masyarakat Desa Penarun Kecamatan Batin VIII Kabupaten Sarolangun yang menjadi anggota Badan Usahan Milik Desa (BUMDes) Desa Penarun dengan ketentuan menyertakan modal pada Badan Usahan Milik Desa (BUMDes) Desa Penarun untuk kemudian dikelola oleh Badan Usahan Milik Desa (BUMDes) Desa Penarun.

Keberadaan Badan Usahan Milik Desa (BUMDes) Desa Penarun seharusnya mampu memberikan dampak positif dalam peningkatan penghasilan masyarakat Desa Penarun Kecamatan Batin VIII Kabupaten Sarolangun karena Desa Penarun Kecamatan Batin VIII Kabupaten Sarolangung sebagian besar berprofesi sebagai petani yang memanfaatkan hasil perkebunan karet dan kelapa sawit.

Badan Usahan Milik Desa (BUMDes) Desa Penarun hingga saat ini masih bergantung pada bantuan swasta maupun Pemerintah Daerah Kabupaten Sarolangun karena tidak mampu untuk mengelola aset yang berasal dari dana masyarakat yang jumlahnya sangat terbatas.

Saat pembentukan Badan Usahan Milik Desa (BUMDes) Desa Penarun disepakati bahwa penyertaan modal masyarakat tidak memiliki nilai ketetapan sehingga dengan demikian masyarakat bebas untuk menyertakan modal pada Badan Usahan Milik Desa (BUMDes) Desa Penarun dan menjadi anggota Badan Usahan Milik Desa (BUMDes) Desa Penarun.

Hal tersebut mengakibatkan Badan Usahan Milik Desa (BUMDes) Desa Penarun memiliki keterbatasan kemampuan untuk mengembangkan usaha, seharusnya dalam pembentukan Badan Usahan Milik Desa (BUMDes) Desa Penarun, baik perangkat desa maupun seluruh lapisan masyarakat Desa Penarun Kecamatan Batin VIII Kabupaten Sarolangun telah memiliki rencana yang matang mengenai pengelolaan Badan Usahan Milik Desa (BUMDes) Desa Penarun sehingga Badan Usahan Milik Desa (BUMDes) Desa Penarun dapat bertahan dan mampu menumbuhkembangkan perekonomian masyarakat Desa Penarun Kecamatan Batin VIII Kabupaten Sarolangun.

Konsep Badan Usahan Milik Desa (BUMDes) seharusnya dibentuk secara mandiri tanpa mengandalkan bantuan dari pihak lain sehingga mampu berkembang dengan baik, akan tetapi Badan Usahan Milik Desa (BUMDes) Desa Penarun selama ini hanya mengharapkan bantuan dari pihak swasta maupun Pemerintah Daerah Kabupaten Sarolangun, sehingga apabila tidak terdapat bantuan dari pihak lain Badan Usahan Milik Desa (BUMDes) Desa Penarun tidak dapat beroperasi. 
Masyarakat merupakan organ terpenting dalam upaya mensukseskan program Badan Usahan Milik Desa (BUMDes) Desa Penarun serta menumbuhkembangkan unit-unit usaha Badan Usahan Milik Desa (BUMDes) Desa Penarun, tanpa adanya kontribusi dari masyarakat tentu Badan Usahan Milik Desa (BUMDes) Desa Penarun tidak dapat bertahan.

Program utama Badan Usahan Milik Desa (BUMDes) Desa Penarun merupakan usaha yang menjadi komoditi utama di Desa Penarun Kecamatan Batin VIII Kabupaten Sarolangun sehingga seharusnya dapat memancing niat dari masyarakat untuk memanfaatkan Badan Usahan Milik Desa (BUMDes) Desa Penarun. Akan tetapi berdasarkan hasil penelitian yang penulis lakukan program Badan Usahan Milik Desa (BUMDes) Desa Penarun tidak dikelola dengan baik oleh pengurus Badan Usahan Milik Desa (BUMDes) Desa Penarun.

Sebagian besar masyarakat Desa Penarun Kecamatan Batin VIII Kabupaten Sarolangun lebih memilih untuk menggunakan pupuk non subsidi untuk memperoleh hasil panen yang lebih maksimal, sedangkan pupuk yang disediakan di Badan Usahan Milik Desa (BUMDes) Desa Penarun merupakan pupuk subsidi yang apabila diaplikasikan pada tanaman kelapa sawit tidak secara signifikan meningkatkan hasil panen sehingga masyarakat Desa Penarun Kecamatan Batin VIII Kabupaten Sarolangun lebih memilih untuk membeli pupuk non subsidi. Pengurus Badan Usahan Milik Desa (BUMDes) Desa Penarun seharusnya menyesuaikan kebutuhan masyarakat desa dengan unit usaha yang disediakan.

Selain minat masyarakat yang masih kurang untuk memanfaatkan Badan Usahan Milik Desa (BUMDes) Desa Penarun, berdasarkan hasil penelitian yang penulis lakukan diketahui bahwa pengurus Badan Usahan Milik Desa (BUMDes) Desa Penarun tidak memiliki inovasi dan kreatifitas dalam mengembangkan Badan Usahan Milik Desa (BUMDes) Desa Penarun, hal tersebut diketahui dari pengelolaan modal swadaya masyarakat yang tidak dimanfaatkan untuk melengkapi kebutuhan-kebutuhan masyarakat desa dalam bentuk unit usaha lain.

Seharusnya pengurus Badan Usahan Milik Desa (BUMDes) Desa Penarun mampu melihat peluang usaha di Desa Penarun Kecamatan Batin VIII Kabupaten Sarolangun salah satunya yaitu tingginya kebutuhan masyarakat akan kebutuhan bahan-bahan pokok rumah tangga.

Berdasarkan penjelasan tersebut maka dapat disimpulkan bahwa pelaksanaan program Badan Usahan Milik Desa (BUMDes) di Desa Penarun Kecamatan Batin VIII Kabupaten Sarolangun tidak terlaksana dengan efektif dimana program usaha yang dijalankan tidak berkembang dan tidak dapat membantu masyarakat Desa Penarun Kecamatan Batin VIII Kabupaten Sarolangun untuk meningkatkan perekonomiannya.

\section{Kendala Pelaksanaan Program Badan Usahan Milik Desa (Bumdes) Di Desa Penarun Kecamatan Batin VIII Kabupaten Sarolangun}

Berdasarkan hasil penelitian yang penulis lakukan diketahui bahwa Badan Usahan Milik Desa (BUMDes) Desa Penarun hingga saat ini tidak mengalami perkembangan dan justru mengalami penurunan disebabkan karena Sumber Daya Manusia pada Badan Usahan Milik Desa (BUMDes) Desa Penarun tidak memiliki inovasi untuk mengembangkan unit usahan pada Badan Usahan Milik Desa (BUMDes) Desa Penarun dengan melihat peluang usaha yang lebih diminati oleh masyarakat Desa Penarun Kecamatan Batin VIII Kabupaten Sarolangun.

Selain itu Sumber Daya Manusia pada Badan Usahan Milik Desa (BUMDes) Desa Penarun tidak memiliki kreatifitas untuk memanfaatkan sumber daya alam ataupun potensi desa untuk dikembangkan sehingga memiliki nilai jual yang dapat dipasarkan baik di Desa Penarun Kecamatan Batin VIII Kabupaten Sarolangun maupun di luar Desa Penarun Kecamatan Batin VIII Kabupaten Sarolangun yang dipengaruhi pula tingkat pendidikan pengurus Badan Usahan Milik Desa (BUMDes) Desa Penarun.

Selain itu berdasarkan hasil penelitian yang penulis lakukan diketahui bahwa keterlibatan masyarakat dalam pengembangan Badan Usahan Milik Desa (BUMDes) merupakan faktor utama berkembangnya Badan Usahan Milik Desa (BUMDes). Tanpa adanya peran serta dari masyarakat suatu Badan Usahan Milik Desa (BUMDes) tidak akan mampu bertahan seperti yang terjadi pada Badan Usahan Milik Desa (BUMDes) Desa Penarun.

Masyarakat Desa Penarun Kecamatan Batin VIII Kabupaten Sarolangun selama ini tidak memanfaatkan keberadaan Badan Usahan Milik Desa (BUMDes) Desa Penarun padahal program usaha yang ditawarkan Badan Usahan Milik Desa (BUMDes) Desa Penarun merupakan unit usaha yang menjadi kebutuhan masyarakat.

Sebagian besar masyarakat Desa Penarun Kecamatan Batin VIII Kabupaten Sarolangun lebih memilih untuk membeli kebutuhan pertanian seperti pupuk, bibit karet dan bibit kelapa sawit dari luar desa padahal jika masyarakat ikut berkontribusi pada Badan Usahan Milik Desa (BUMDes) Desa Penarun diyakini Badan Usahan Milik Desa (BUMDes) Desa Penarun dapat berkembang dengan baik.

Berdasarkan penjelasan tersebut diketahui bahwa masyarakat tidak memiliki kontribusi besar dalam pengembangan Badan Usahan Milik Desa (BUMDes) Desa Penarun padahal Badan Usahan Milik Desa (BUMDes) dibentuk untuk mempercepat perekonomian masyarakat dengan memberdayakan unit usaha yang dikelola oleh masyarakat melalui Badan Usahan Milik Desa (BUMDes) Desa Penarun. 
Upaya Yang Dilakukan Untuk Mengatasi Kendala Pelaksanaan Program Badan Usahan Milik Desa (Bumdes) Di Desa Penarun Kecamatan Batin VIII Kabupaten Sarolangun

Kedepannya Badan Usahan Milik Desa (BUMDes) Desa Penarun akan menjadi wadah pemasaran industri kreatif rumah tangga masyarakat Desa Penarun Kecamatan Batin VIII Kabupaten Sarolangun karena masyarakat Desa Penarun Kecamatan Batin VIII Kabupaten Sarolangun belakangan ini sering memperoleh pelatihan dari Dinas Pemberdayaan Masyarakat dan Desa Kabupaten Sarolangun terutama dalam bentuk industry pangan perumahan.

Masyarakat Desa Penarun Kecamatan Batin VIII Kabupaten Sarolangun kedepannya diharapkan dapat memproduksi makanan ringan yang berasal dari umbi-umbian yang diolah menjadi makanan ringan dan telah mendapatkan bantuan dari pemerintah untuk dapat mengolah makanan ringan tersebut.

Badan Usahan Milik Desa (BUMDes) Desa Penarun diharapkan dapat menjadi wadah penyalur hasil industri rumahan masyarakat Desa Penarun Kecamatan Batin VIII Kabupaten Sarolangun sehingga unit usaha Badan Usahan Milik Desa (BUMDes) Desa Penarun menjadi lebih beragam dan dapat meningkatkan perekonomian masyarakat desa.

Selain sebagai pemasar produk industri rumahan masarakat Desa Penarun, Badan Usahan Milik Desa (BUMDes) Desa Penarun juga akan menyediakan kebutuhan pokok masyarakat desa dan kebutuhan produksi industri rumahan masyarakat Desa Penarun. Dengan demikian diharapkan kedepannya Badan Usahan Milik Desa (BUMDes) Desa Penarun dapat menjadi salah satu penopang perekonomian masyarakat Desa Penarun Kecamatan Batin VIII Kabupaten Sarolangun.

Pengembangan unit usaha tersebut sekaligus mampu menarik keterlibatan masyarakat Desa Penarun Kecamatan Batin VIII Kabupaten Sarolangun untuk mengembangkan Badan Usahan Milik Desa (BUMDes) Desa Penarun sehingga masyarakat turut merasa bertanggungjawab terhadap pengelolaan Badan Usahan Milik Desa (BUMDes) Desa Penarun. Dengan adanya keterlibatan masyarakat dalam pengembangan Badan Usahan Milik Desa (BUMDes) Desa Penarun diharapkan kedepannya Badan Usahan Milik Desa (BUMDes) Desa Penarun dapat lebih maju dan memiliki kontribusi atas kemajuan Desa Penarun Kecamatan Batin VIII Kabupaten Sarolangun.

\section{SIMPULAN}

Dari penjelasan sebagaimana telah diuraikan di dalam pembahasan tersebut di atas maka dalam hal ini Penulis menarik suatu kesimpulan dari penelitian ini yaitu :

1. Program Badan Usahan Milik Desa (BUMDes) di Desa Penarun Kecamatan Batin VIII Kabupaten Sarolangun tidak terlaksana dengan efektif dimana program usaha yang dijalankan tidak berkembang dan tidak dapat membantu masyarakat Desa Penarun Kecamatan Batin VIII Kabupaten Sarolangun untuk meningkatkan perekonomiannya.

2. Kendala pelaksanaan program Badan Usahan Milik Desa (BUMDes) di Desa Penarun Kecamatan Batin VIII Kabupaten Sarolangun terdiri dari beberapa faktor yaitu tidak adanya Sumber Daya Manusia yang memiliki inovasi dan kreatifitas pada Badan Usahan Milik Desa (BUMDes) Desa Penarun Kecamatan Batin VIII Kabupaten Sarolangun serta tidak adanya peran serta masyarakat untuk mengembangkan Badan Usahan Milik Desa (BUMDes) Desa Penarun Kecamatan Batin VIII Kabupaten Sarolangun.

3. Upaya yang dilakukan untuk mengatasi kendala pelaksanaan program Badan Usahan Milik Desa (BUMDes) di Desa Penarun Kecamatan Batin VIII Kabupaten Sarolangun yaitu melakukan pengembangan unit usaha serta menjalain kerjasama dengan Badan Usahan Milik Desa (BUMDes) Lainnya.

\section{DAFTAR PUSTAKA}

\section{Buku}

Bahder Johan Nasution, Metode Penelitian Ilmu Hukum, Mandar Maju, Bandung, 2008.

CST. Kansil, Kamus Besar Bahasa Indonesia, Bitra Indonesia, Medan, 2013.

Nurcholis Hanif, Pertumbuhan dan Penyelenggaraan Pemerintahan Desa, Penerbit Erlangga, Jakarta, 2011.

Ranuhandoko, Terminologi Hukum, Sinar Grafika, Jakarta, 2008.

Riduan Syahrani, Rangkuman Intisari Ilmu Hukum, Citra Aditya Bakti, Bandung, 1999.

Salim HS, Erlies Septiana Nurbaini, Penerapan Teori Hukum Pada Penelitian Tesis dan Disertasi, RajaGrafindo Persada, Jakarta, 2016.

Sayogya, Sosiologi Pedesaan, Gadjah Mada University Press, Yogyakarta, 2000.

Soerjono Soekanto, Sosiologi Suatu Pengantar, Pers, Jakarta, 2009.

Soetardjo Karto Hadi Koesoemo, Desa, Sumur, Bandung, 2000.

Talizihudu Ndraha, Dimensi-Dimensi Pemerintahan Desa, Bina Aksara, Jakarta, 1981. , Pembangunan Masyarakat: Mempersiapkan Masyarakat Tinggal Landas, Bina Aksara, Jakarta,

1987.

Tim Prima Pena, Kamus Besar Bahasa Indonesia, Gita MediaPress, 2014. 
Kemas Abdul Somad dan H. Zikri, Pelaksanaan Program Badan Usahan Milik Desa (Bumdes) di Desa Penarun Kecamatan

\section{Peraturan Perundang-Undangan}

Republik Indonesia, Undang-Undang Nomor 23 Tahun 2014 Tentang Pemerintahan Daerah. Undang-Undang Republik Indonesia Nomor 6 Tahun 2014 Tentang Desa

Republik Indonesia, Peraturan Pemerintah Republik Indonesia Nomor 11 Tahun 2019 Tentang Perubahan Kedua Atas Peraturan Pemerintah Nomor 43 Tahun 2014 Tentang Peraturan Pelaksanaan Undang- Undang Nomor 6 Tahun 2014 Tentang Desa.

Republik Indonesia, Peraturan Menteri Desa, Pembangunan Daerah Tertinggal, dan Transmigrasi Republik Indonesia Nomor 4 Tahun 2015 Tentang Pendirian, Pengurusan Dan Pengelolaan, Dan Pembubaran Badan Usaha Milik Desa

Republik Indonesia, Peraturan Daerah Kabupaten Sarolangun Nomor 39 Tahun 2004 Tentang Pembentukan Kecamatan Batin VIII

Republik Indonesia, Peraturan Bupati Sarolangun Nomor 56 Tahun 2018 Tentang Pendirian, Pengurusan Dan Pengelolaan, Dan Pembubaran Badan Usaha Milik Desa

\section{Jurnal}

Ahmad Nur Ihsan, Analisis Pengelolaan Badan Usaha Milik Desa (BUMDes) Gerbang Lentera Sebagai Penggerak Desa Wisata Lerep, Jurnal Ilmu Hukum, Universitas Diponegoro, 2015.

Didik Sukriono, Politik Hukum Pemerintahan Desa di Indonesia, Jurnal Konstitusi Volume 1, PKK Universitas Kanjuruhan Malang, Malang, 2008.

Jefri S.Pakaya, Pemberian Kewenangan Pada Desa Dalam Konteks Otonomi Daerah, Jurnal Legislasi Indonesia, Volume 13 Nomor 01, 2016.

M. Muslih, Masriyani dan Ryanda Putra Pratama, Pelaksanaan Program Badan Usaha Milik Desa (BUMDes) Di Kecamatan Jambi Luar Kota Kabupaten Muaro Jambi, Jurnal Wajah Hukum, Universitas Batanghari, Volume 4, Nomor 2, Oktober 2020. 